\title{
UNUSUALLY LARGE FLOCK OF KNOTS AND RUDDY TURNSTONES FEEDING IN STUBBLE FIELD
}

by Fred W. Lahrman, Saskatchewan Museum of Natural History, Regina

On May 21, 1972, while observing birds at the north end of Last Mountain Lake, I was surprised to discover a large flock of shore birds feeding on a burned-over stubble field of Durum wheat. The flock was huge and I estimated it must have contained at least 5,000 birds.

I was even more surprised when I discovered that it consisted mainly of Knots and Ruddy Turnstones for I do not recall seeing these species feeding on dry land before. There appeared to be slightly more Knots than Turnstones. Other birds noted feeding on the field were 12 Black-bellied Plovers, a few Ring-billed Gulls, Franklin's Gulls, approximately 15 Pintails and a pair of Widgeons.

The field was located approximately $1 / 2$ mile west of the lakeshore and southeast of Liberty, and the birds were observed between $7: 30$ and 8:00 p.m. They presented a lovely view as they moved busily over the ground, feeding as they went along. They often burst into sudden flight as shorebirds will and after erratically flying about in their twisting formation, they would settle on a different part of the field sometimes separating into two or three groups, and at other times uniting into one again.

Earlier in the afternoon I had noticed flocks numbering up to 30 or more birds feeding along the lakeshore and flying northwards up the lake. I do not know why they chose this certain field or what particular food attracted them.

In previous years, I had noted that the week of May 20 was the time when the peak of the migration of these birds passed through, but I have never seen such large numbers as this.

Also noted in larger numbers than usual were Stilt Sandpipers of which flocks of hundreds were seen feeding in shallow bays along the lakeshore and nearby sloughs.

\section{TWELFTH ANNUAL NESTBOX REPORT OF THE BRANDON JUNIOR BIRDERS}

\section{by John Lane, 1701 Lorne Avenue and Randy Bauman, 431 17th Street, Brandon, Manitoba}

Since our last report our club has built 375 more nestboxes and had another 125 donated by J. Plum and H. Watson. With the aid of an open winter all 500 were set out by last Spring, repeated trips being made during both Christmas and Easter vacations. This brings our overall total to 3500 nestboxes set out since 1959, of which we estimate 250 as no longer habitable. Our nestlines now extend over 1000 miles of highway and railway. Many Mountain Bluebirds and the earlier Eastern Bluebirds were appearing along our nestlines by mid-
March, and we found the first eggs of both in late April. Cross-breeding between the two species continues to increase, three cases of Eastern males mated to Mountain females being noted. In addition, two more male hybrids were found, in each case mated to Mountain females. The first instance occupied Nestbox 1238, east of Carberry on Highway No. 1; his mate laid and hatched five eggs and raised the nestlings without aid since the hybrid father disappeared when the young first appeared. The other hybrid was found at Nestbox 129 southeast of 
Griswold, mated to a Mountain hen which we had banded last year as a juvenile in another nestbox just $1 \frac{1}{4}$ miles away. After the five eggs hatched at this second nest, we set up a blind and took many pictures, mainly of the male bluebird, since he was a most unusual looking specimen: in addition to an extremely deep blue back and blue throat, he had much chestnut down his flanks, raising the question as to whether he might be a cross between the Mountain and West. ern Bluebirds.

The "Southeast Line" under Ed Robinson's direction listed 58 bluebird nestings from 100 nestboxes, an excellent percentage. The "Southwest Line" with Stan Giles and Art Michie in charge had an equally good percentage of success and in addition one of the nests in this area held the first Cowbird's egg ever found on our nestlines. We are sorry to report that the Rev. H. Dykman, who started our "Northwest Line" several years ago, has moved with his family to B.C., and his extensive nestline, running from south of Kenton north to Hamiota, west to Miniota, and south to Hargrave, has now been added to our main complex.

The banding of bluebirds again occupied much of our time this summer. Beginning in late May we banded until early August with a total of 4162 bluebirds. Of this total, 3475 were Mountain Bluebirds, 662 Easterns, and 25 hybrids. West of Brandon the malady which struck the firstbrood young in 1970 , as reported in Blue Jay, Dec., 1970, recurred this summer in the same areas. An esti. mated 100 nests were affected and 450 young bluebirds died, including the first two broods of hybrids. Specimens sent to a laboratory in Winnipeg for tests failed to reveal any concrete causes, but specimens of a small fly which we invariably found sucking blood from the young in the affected nests were identified as the common black-fly, and we now believe these, rather than some poison spray, to be the cause of the epidemic. In addition to these newly-established enemies of the bluebirds, we found a flying squir- rel in one nestbox, and paper-making wasps which had taken over in another. These insects completely shrouded the box in their grey paper, then built their tiers of combs inside. In areas of evergreens porcupines are becoming a nuisance by climbing fenceposts and chewing up those nestboxes which are partly built of plywoods; we have been told it is the glue they are after. Deer mice, House Sparrows, House Wrens, and several types of ants continue to invade our nests, with both mice and sparrows on the increase. Starling have not become the menace that we feared, possibly because we are now installing smaller holes over the normal nesthole in areas where this species threatens. Our total nestings for 1972 are:

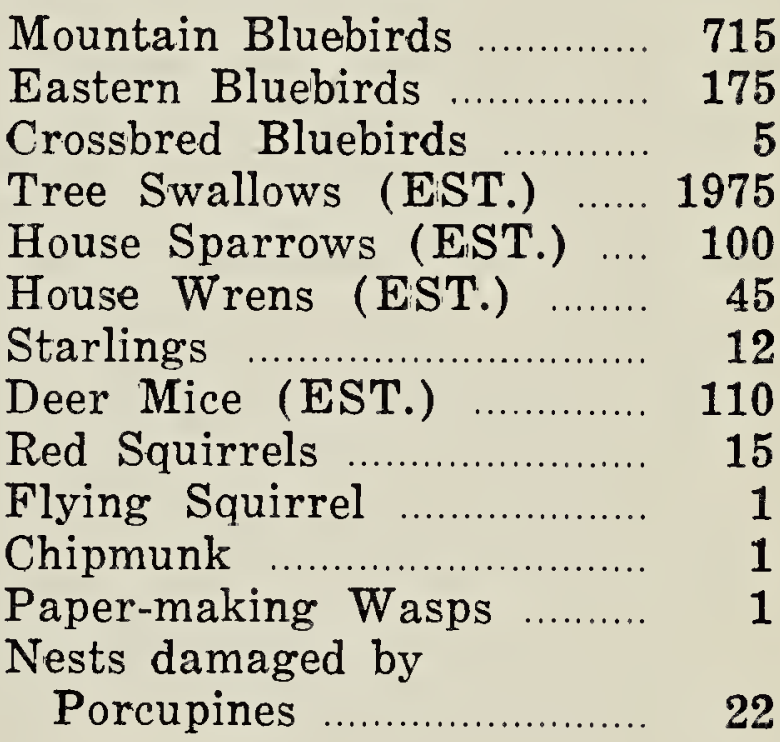

\section{ANNUAL REPORT ON THE INDIAN HEAD BLUEBIRD TRAIL}

An additional 200 nest boxes were set out last spring, bringing the 10 year total to over 1,400 houses. Two new trails were established; one runs southeast of Regina along highway No. 16 to highway No. 35, then north on No. 35 to the Trans-Canada Highway. The other trail runs northwest of Regina on highway No. 11 to Lumsden, then north on highway No. 20 along the east side of Last Mountain Lake past Silton.

There were about 250 nests of Mountain Bluebirds in the houses this year, an increase of some 50 nests over last year. About 1,000 young (Continued on page 253) 